\title{
Recent establishments and extinctions of Northern Gannet Morus bassanus colonies in North Norway, 1995-2008
}

\author{
Robert T. Barrett
}

\begin{abstract}
Barrett, R.T. 2008. Recent establishments and extinctions of Northern Gannet Morus bassanus colonies in North Norway, 1995-2008. - Ornis Norvegica 31: 172-182.

Since the last published review of the development of the Northern Gannet Morus bassanus population in Norway (Barrett \& Folkestad 1996), there has been a general increase in numbers breeding in North Norway from ca. 2200 occupied nests in 1995 to ca. 2700 in 2008. In Lofoten and Vesterålen, however, numbers have decreased from 1500 occupied nests in 1989 to 500 in 2008, and what were the two largest colonies on Skarvklakken and Hovsflesa have been abandoned. Small colonies have, in the meantime, been established in the region, but these are all characteristically unstable. A new colony established in Troms in 2001 increased to 400 occupied sites in 2007, but the population dropped to 326 in 2008. Harassment by White-tailed eagles Haliaeetus albicilla is mooted as the main cause of the decline in Lofoten and Vesterålen.
\end{abstract}

Robert T. Barrett, Dept. of Natural Science, Troms $\phi$ University Museum, N-9037 Troms $\phi$, Norway.

\section{INTRODUCTION}

Apart from perhaps the Great Skua Catharacta skua, there is no species whose establishment as a breeding bird in Norway and subsequent population development has been so well documented as that of the Northern Gannet Morus bassanus (Folkestad et al. 1980, Vader 1980, Barrett \& Folkestad 1996 and refs. therein). Also globally, the population recovery of the Northern Gannet, which breeds only in the North Atlantic, has been thoroughly documented since their protection in the late 1800s and early 1900s after decades of human persecution in the $19^{\text {th }}$ century (Nelson 2002, Wanless et al. 2005). Northern Gannets started their colonisation of Norway at Runde, Møre and Romsdal in the mid 1940s, and spread to North Norway in the early 1960s where the population increased to ca. 2200 pairs on five colonies in 1995 (Barrett \& Folkestad 1996). Characteristically for any new establishment, the Northern Gannet population in Norway increased very rapidly (>20\% p.a.) during the first two decades, and then slowed to a possible culmination in the 1990s (Barrett \& Folkestad 1996). In two of the well-established colonies, Skarvklakken and Hovsflesa in the north of the country, there were even signs of declines between 1991 and 1995 . This paper documents the subsequent fate of the North Norwegian colonies, including the extinction of some and the establishment of others.

\section{METHODS}

Nearly all Northern Gannet colonies in Finnmark, Troms and northern Nordland (Fig. 1) were censussed at 1-4 year intervals. Counts of nest-site holding pairs (single or pairs of birds at sites where nest material was observed) were made either directly while visiting the colony (ground counts), from photographs taken on land (Syltefjord) or from aerial photographs (taken from ca. $150 \mathrm{~m}$, airspeed ca. 100 knots). More details are given in Montevecchi et al. (1987) and dates of counts are given in Table 1. Many of the colonies were established among nesting Great Cormorants Phalacrocorax carbo, and counts were thus also made of the cormorants to monitor the effects of this intrusion. Counts from photographs up to and including 2004 were made using colour 
prints whereas subsequent counts were made using screen images of digital photographs. Some estimates were also made through telescopes from the mainland (Kvalnesflesa and Skarvklakken). Reports of the establishment of new colonies in the region from local fishermen and/or bird watchers were followed up during the aerial surveys as soon as possible in subsequent years.

\section{RESULTS}

\section{Syltefjord $70^{\circ} 36^{\prime} \mathrm{N}, 30^{\circ} 18^{\prime} \mathrm{E}$}

The gannetry at Syltefjord was established among Black-legged Kittiwakes Rissa tridactyla and Common Guillemots Uria aalge on a large stack (Fig. 2A) in 1967 and the population rose to ca. 480 occupied nests in the mid 1990s (Brun 1967, Barrett \& Folkestad 1996). Since then, three counts (in 1999, 2002 and 2007) showed a stabilization at this level (Table 1) before what appears to be an increase in 2008 to 600 occupied nests. Throughout its history, this colony has been restricted to the sides and top of the original stack and no attempts to breed on the main seabird cliff behind have been reported.

\section{Storstappen $71^{\circ} 09^{\prime} \mathrm{N}, 25^{\circ} 19^{\prime} \mathrm{E}$}

This colony (Fig. 2B), on the outermost island of the Gjesvær archipelago is the most successful in the region being established in 1987 and reaching 500 occupied nests by 1995 (Barrett \& Folkestad 1996). Since then it has increased further to ca. 1200-1300 occupied nests in 2008 (Table 1) and has almost filled what was otherwise a grasscovered terraced slope. A small subcolony was established on a small shelf ca. $20 \mathrm{~m}$ above the main colony in 1999 and numbered ca 20 occupied nests in 2005, 12 in 2006 and 18 in 2008.

\section{Kvitvær $70^{\circ} 13^{\prime} \mathrm{N}, 18^{\circ} 42^{\prime} \mathrm{E}$}

The colony at the Kvitvær archipelago (Fig. 2C) was first reported in May 2001 when 70-80 birds and nests with eggs on Flatskjeran were reported to the County Governor in Troms (K.-O. Jacobsen, pers. comm.). The gannets were nesting in an already existing colony of Great Cormorants. A survey by the Norwegian Institute for Nature

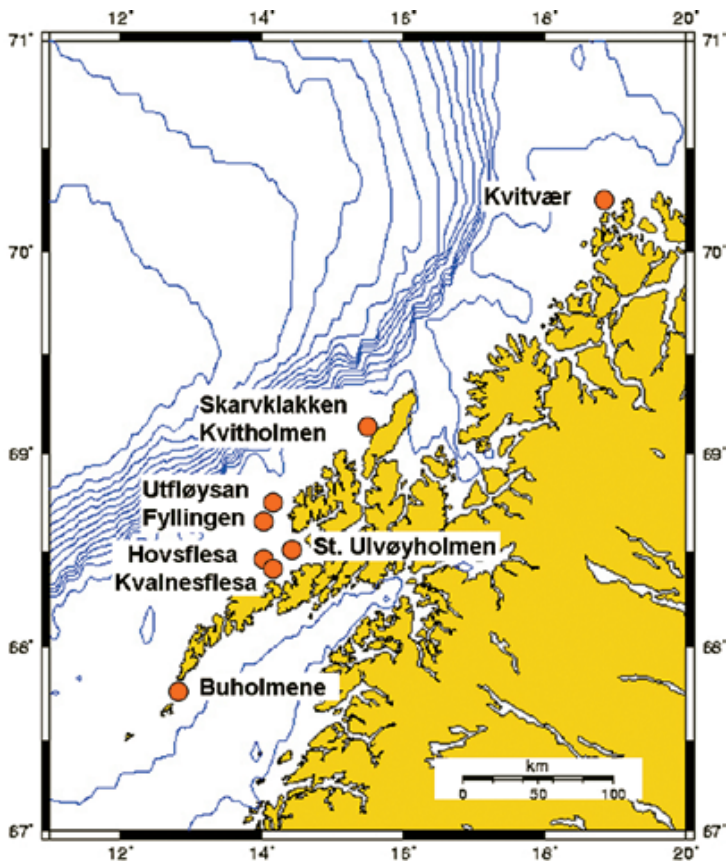

Figure 1. Positions of known Northern Gannet colonies in Lofoten, Vesterålen and Troms in 1995-2008.

research in June confirmed this report and ca. 30 nests were counted on aerial photographs. Numbers of gannets increased rapidly and already in 2002 the population had reached 170-180 occupied nests. It increased further to 400 occupied nests in 2007 but in 2008 it had decreased to 326 occupied nests (Table 1). Concurrent with the increase in gannet numbers was an increase in the numbers of occupied cormorant nests from ca. 200 in 2002 to 340 in 2006, since when numbers dropped to 180 occupied nests in 2007 and 2008. No cormorants or any sign of nest-building by cormorants were seen during the survey in 2005 , probably a result of an abandoned breeding attempt that year rather than a collapse in breeding population.

\section{Skarvklakken $69^{\circ} 09^{\prime} \mathrm{N}, 15^{\circ} 39^{\prime} \mathrm{E}$}

After its establishment in 1967, the colony on Skarvklakken (ca. $4 \mathrm{~km}$ from the tip of the breakwater at Nordmela, Andøya, Fig. 2D) increased to nearly 1000 occupied nests in 1991 (Barrett $\&$ Folkestad 1996). Since then, numbers have dropped steadily and the colony is now abandoned 
Table 1. Counts of nest-site holding pairs of Northern Gannets in North Norwegian gannetries. - indicates no counts made. All counts are from aerial photographs with the exception of those at Syltefjord and those marked with superscript which are estimates made from land or boat. Figures in brackets are estimates early in a season in which the colony was later found abandoned.

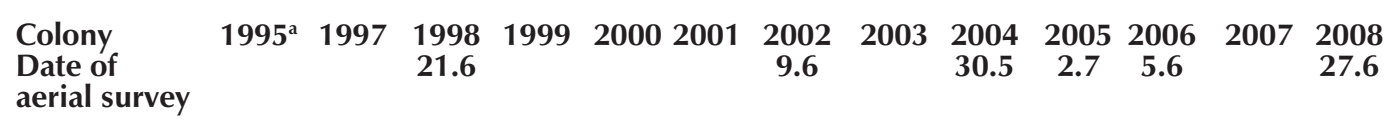

\begin{tabular}{|c|c|c|c|c|c|c|c|c|c|c|c|c|c|}
\hline Syltefjord & 481 & - & - & 473 & - & - & 479 & - & - & - & - & $481^{\mathrm{b}}$ & 600 \\
\hline Storstappen & 516 & - & - & 1000 & - & - & 1100 & - & - & 1230 & 1180 & $1364^{\mathrm{c}}$ & 1244 \\
\hline Kvitvær & - & - & - & - & - & $30^{\mathrm{b}}$ & 175 & - & 225 & 250 & 341 & 400 & 326 \\
\hline Skarvklakken & $730-760$ & $600^{d}$ & 410 & 240 & - & $353^{d}$ & 205 & $(30-40)^{\mathrm{e}}$ & $(30-50)^{\mathrm{e}}$ & e 0 & 7 & $0^{i}$ & 0 \\
\hline Kvitholmen & - & - & - & - & - & - & - & - & - & - & 0 & - & 50 \\
\hline Utfløysan & - & - & 45 & - & - & - & 0 & - & 0 & 0 & 0 & - & 0 \\
\hline Fyllingen & - & $7^{f}$ & 20 & - & - & - & 100 & - & 180 & 60 & 34 & ca. $30^{g}$ & 0 \\
\hline St. Ulvøyhomen & - & $15-20^{h}$ & 70 & - & - & - & 405 & - & 455 & 280 & 320 & $377^{c}$ & 308 \\
\hline Kvalnesflesa & - & - & 0 & - & - & - & 70 & - & 25 & 0 & 0 & $20-30$ & 76 \\
\hline Hovsflesa & $460-470$ & $320^{i}$ & 320 & $240^{\mathrm{i}}$ & $230^{i}$ & $(<100 ?)^{\mathrm{i}}$ & 0 & 0 & 0 & 0 & 0 & 0 & 0 \\
\hline Buholmene & - & - & - & - & - & - & - & - & - & - & - & 28 & 126 \\
\hline
\end{tabular}

${ }^{a}$ From Barrett \& Folkestad (1996), ${ }^{b}$ NINA, ${ }^{c}$ Emeline Pettex pers. comm., ${ }^{d}$ pers. obs. ground count, ${ }^{e}$ Bjørn R $\phi$ sshag pers. comm., ${ }^{f}$ Harald Bergmann pers. comm. ${ }^{g}$ Roger Vagle pers. comm., ${ }^{h}$ Håkon Jenssen pers. comm., ${ }^{i}$ Harald Våge pers. comm., ${ }^{j}$ Espen Bergersen, pers. comm.

(Table 1). In 2002, more than 200 occupied nests were counted during the aerial survey on 9 June. In 2003, gannets started to nest as usual but the colony was abandoned by the end of May (Bj. Røsshag pers. comm.). Only 30-40 empty nests and no adults were seen during a visit on 30 June. Similarly in 2004, up to 50 pairs were seen from land in early May (Bj. Røsshag pers. com) but on 30 May none were seen during the aerial survey. A few pairs returned to the island later with ca. 40 birds being seen on 9 June and 8-10 pairs being seen from land in July, but again in August the island was empty (E. Bergersen, W. Vader, Bj. Røsshag pers. comm.). In 2006, a few gannets were seen on and over the island in mid-April (E. Bergersen pers. comm.) and seven occupied nests were counted in early June, but in 2008 there was again no sign of gannets on the island. The last year cormorants were documented as breeding on Skarvklakken was 1995 when 25-30 occupied nests were counted.

\section{Kvitholmen $69^{\circ} 09^{\prime} \mathrm{N}, 15^{\circ} 41^{\prime} \mathrm{E}$}

Kvitholmen (Fig. 2E) is a small islet about 500 $m$ southeast of Skarvklakken on which Northern Gannets were first observed breeding in 2008. No gannets were seen among 120 Great Cormorant nests during the aerial survey in 2006 and nor were any seen from land in May 2007 (E. Bergersen pers. comm.). In 2008, 50 occupied gannet nests were counted among 160 Great Cormorant nests.

\section{Utfløysan $68^{\circ} 39^{\prime} \mathrm{N}, 14^{\circ} 15^{\prime} \mathrm{E}$}

Northern Gannets were found breeding on this small islet (Fig. 2F) once only, in 1998 when 45 occupied nests were counted among 115 Great Cormorant nests. Breeding of Great Cormorants had been documented since 1985 (250 pairs) and at the last count prior to the establishment of the gannetry, in 1995, the population was 110 pairs. At the next census after the 1998 count, in 2002, the colony had been abandoned by both species and has remained so since.

\section{Fyllingen $68^{\circ} 38^{\prime} \mathrm{N}, 14^{\circ} 16^{\prime} \mathrm{E}$}

This small islet (Fig. 2G) is approximately $3 \mathrm{~km}$ south of Utfløysan and was colonised by Northern Gannets in 1997 when 7-8 nests were reported (H. Bergmann pers. comm.) among the 200-250 Great Cormorant nests (Table 1). This was confirmed during an aerial survey in 1998 when 17 nests (and 120 birds) were counted, and in 1999, 128 adults were counted from the sea (H. Våge pers. comm.). 
The cormorant population increased in size to 400 occupied nests in 2002 and that of the gannet to 180 occupied nests in 2004. In 2005 numbers of both species had dropped by $70-80 \%$ (with 80 occupied and ca. 105 abandoned cormorant nests being counted), and although 34 occupied gannet and 99 occupied cormorant nests were counted during the aerial survey on 5 June 2006, both species had abandoned the colony by 31 July (A. Oxem pers. comm.). No nests of either species were found in 2008 .

\section{St. Ulvøyholmen $68^{\circ} 31^{\prime} \mathrm{N}, 14^{\circ} 31^{\prime} \mathrm{E}$}

The first Northern Gannet nests on Store Ulvøyholmen (Fig. 2H) were found in 1997 when 15-20 nests were reported by locals within a Great Cormorant colony. An aerial survey the following year documented 70 occupied gannet nests and 315 cormorant nests. While the gannet population increased to 455 pairs in 2004 and remained $>300$ pairs in subsequent years (Table 1), the numbers of cormorants dropped rapidly between 2004 and 2006 and no nests were found in 2007 and 2008. There were signs of a breeding failure among the cormorants in 2005 with only two occupied nests (and 20 abandoned) being counted on 2 July.

\section{Hovsflesa $68^{\circ} 22^{\prime} \mathrm{N}, 14^{\circ} 00^{\prime} \mathrm{E}$}

Skarvklakken and Hovsflesa (established 1975, Fig 2I) were the only extant Northern Gannet colonies in the region in 1995 (Barrett \& Folkestad 1996). Like Skarvklakken, the colony on Hovsflesa (460-470 occupied nests in 1995) declined during subsequent years to 230 pairs in 2000 and was found abandoned in June 2001. About 130 birds had been seen on the island in early April 2001, but none were present two months later $(\mathrm{H}$. Våge pers. comm.). The first gannets to breed on Hovsflesa did so within a colony of Great Cormorants (Barrett 1981), the size of which increased from ca. 110 pairs in 1975 to nearly 300 pairs in1985, after which it dropped to 10 pairs in 1991 , and was abandoned in 1995.

\section{Kvalnesflesa $68^{\circ} 21^{\prime} \mathrm{N}, 13^{\circ} 59^{\prime} \mathrm{E}$}

Two groups of low-lying islets ca. $2.5 \mathrm{~km}$ from land make up the archipelago Kvalnesflesa (Fig.
2J). Northern Gannets were first seen from land on the innermost group (ca. $1 \mathrm{~km}$ offshore) on 21 May 2002 (H. Våge pers. comm.) and 70 occupied nests were counted during the aerial survey on 9 June. However, no birds were seen on or above the colony from land on 18 August, and the breeding attempt was assumed to have been abandoned (Våge \& Stenersen 2003). Similarly, 20-30 birds were seen on nests from land at the end of May 2003 , but the colony was again abandoned by early August (Våge \& Stenersen 2003). Ca. 25 occupied nests were counted from the air 30 May 2004, but none were seen in 2005 and 2006. In 2007, a recolonisation had occurred (20-30 occupied nests) and even more nests (76) were counted in 2008 (Table 1). There was, however, no sign of any birds when viewed from land in the middle of August 2008, suggesting a complete breeding failure (H. Våge pers. comm.). Again this colony was established within an already existing Great Cormorant colony whose population was about 200 occupied nests between 1998 and 2006, and which increased to 370 occupied nests in 2008. In 2005 , ca. 220 nests were counted on aerial photographs, but all had been abandoned.

\section{Buholmene $67^{\circ} 46^{\prime} \mathrm{N}, 12^{\circ} 45^{\prime} \mathrm{E}$}

In 2007, reports were received of ca. 30 pairs of Northern Gannets breeding on Buholmene (Fig. $2 \mathrm{~K}$ ) on the outer end of Lofoten, and that they had been seen in the area by fishermen over the last 8-9 years (F. Christensen pers. comm.). The aerial survey in Lofoten and Vesterålen was thus extended in 2008 and confirmed this report with a count of 126 occupied nests on three small islands within the archipelago and among ca. 500 Great Cormorant nests. There is no earlier documentation of this colony which lies $1.5 \mathrm{~km}$ east of Skittenskarvholmen where Northern Gannets established a colony in 1960 among < 100 pairs of Great Cormorant (Brun 1972). This colony grew to ca. 85 pairs by 1975, but was found abandoned in 1978 (Barrett 1979) and was not again surveyed until 2008 when there was no sign of breeding of either species.

\section{Overall numbers}

Although the numbers of gannets breeding on 

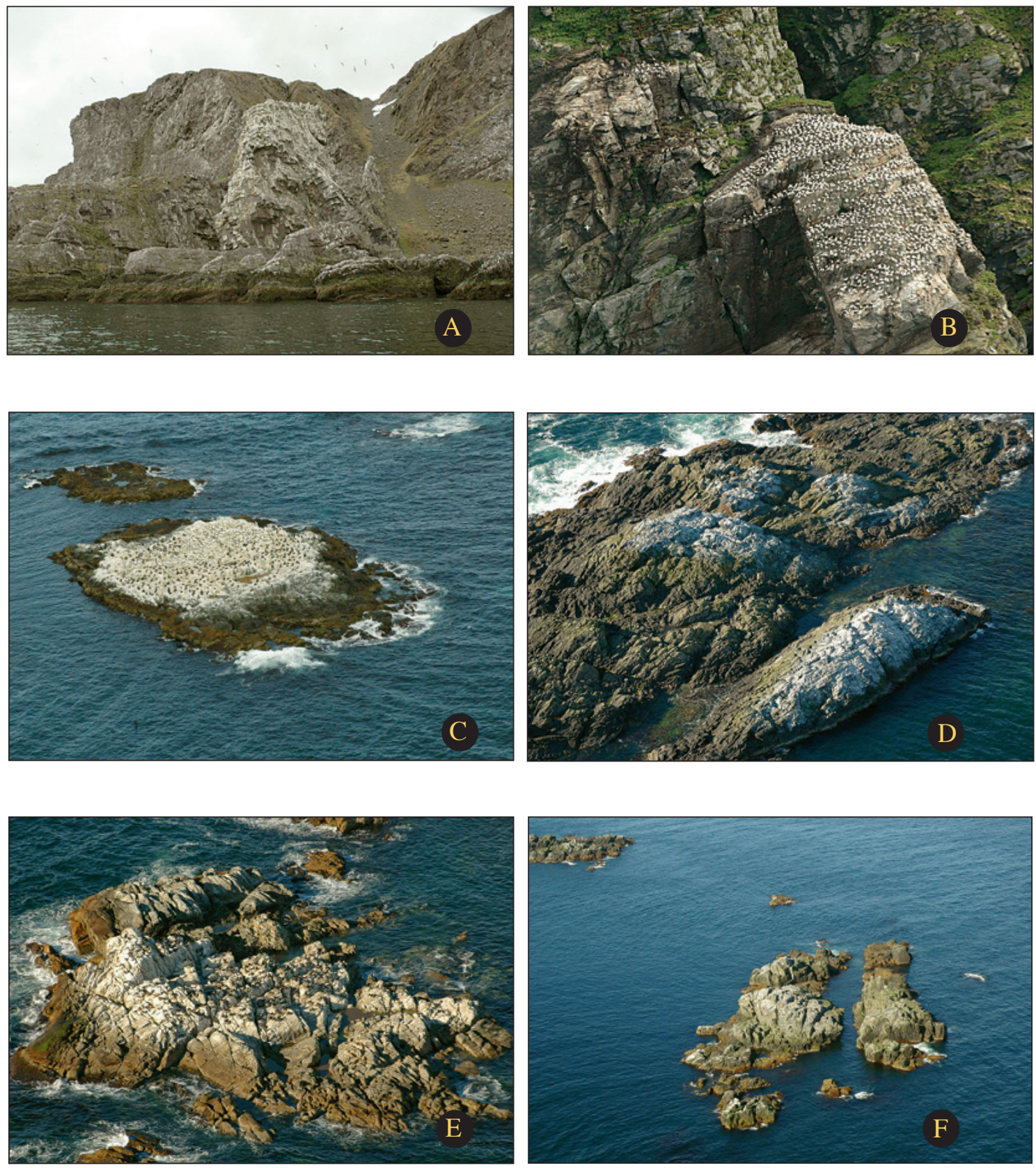

Figure 2. Northern Gannet colonies in North Norway. A - Syltefjord, B - Storstappen, C - Kvitvar, D - Skarvklakken, E-Kvitholmen, F-Utfløysan. 

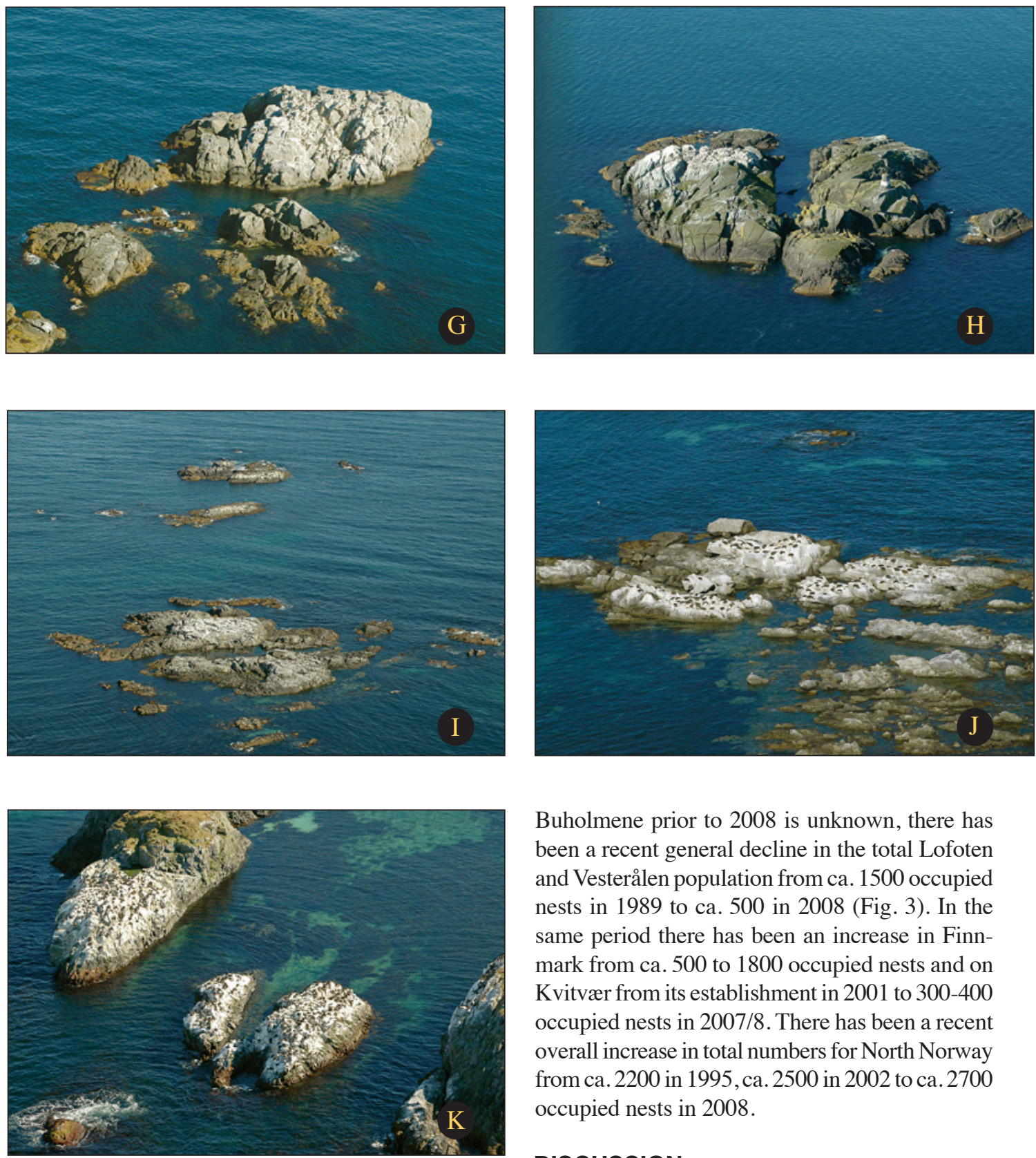

Buholmene prior to 2008 is unknown, there has been a recent general decline in the total Lofoten and Vesterålen population from ca. 1500 occupied nests in 1989 to ca. 500 in 2008 (Fig. 3). In the same period there has been an increase in Finnmark from ca. 500 to 1800 occupied nests and on Kvitvær from its establishment in 2001 to 300-400 occupied nests in 2007/8. There has been a recent overall increase in total numbers for North Norway from ca. 2200 in 1995, ca. 2500 in 2002 to ca. 2700 occupied nests in 2008 .

\section{DISCUSSION}

Because actual nests are often visible on

Fig. 2. cont'd. Northern Gannet colonies in North Norway. G-Fyllingen, H-St. Ulv $\phi y$ holmen, I-Hovsflesa, J-Indre Kvalnesflesa, $K$-Buholmene.

the photographs (Fig. 4), counting apparently occupied nests on aerial photographs is seemingly simple when colonies are small as in North Norway. There are, however, inherent errors in any conversion to numbers of breeding pairs as a result 
Table 2. Ringing controls of 18 adult Northern Gannets on St. Ulvøyholmen, Vesterålen.

\begin{tabular}{|c|c|c|c|c|}
\hline Ring no & $\begin{array}{l}\text { Year of } \\
\text { control }\end{array}$ & $\begin{array}{c}\text { Where last } \\
\text { seen }\end{array}$ & $\begin{array}{c}\text { When last } \\
\text { seen }\end{array}$ & Seen as \\
\hline 251330 & 2003 & Storstappen & 1991 & $\mathrm{ad}^{\mathrm{a}}$ \\
\hline 255041 & 2003 & Skarvklakken & 2001 & ad. \\
\hline 255442 & 2003 & Hovsflesa & 1985 & pull. \\
\hline 255594 & 2008 & Hovsflesa & 1985 & pull. \\
\hline 255598 & 2003 & Hovsflesa & 1985 & pull. \\
\hline 263553 & 2008 & Hovsflesa & 1986 & pull. \\
\hline 264686 & 2008 & Skarvklakken & 1988 & pull. \\
\hline 266584 & 2008 & Skarvklakken & 1989 & pull. \\
\hline 268166 & 2008 & Skarvklakken & 1997 & ad.c \\
\hline 273395 & 2008 & Skarvklakken & 1997 & pull. \\
\hline 273964 & 2008 & Skarvklakken & 1998 & pull. \\
\hline 273895 & 2008 & Skarvklakken & 1997 & pull. \\
\hline 277828 & 2003 & Hovsflesa & 1996 & pull. \\
\hline 277924 & 2007 & Hovsflesa & 1997 & ad. \\
\hline 277998 & 2003 & Hovsflesa & 1997 & ad. \\
\hline 283508 & 2003 & Hovsflesa & 1997 & ad. \\
\hline 283621 & 2003 & Hovsflesa & 1997 & pull. \\
\hline 284141 & 2008 & Hovsflesa & 1999 & pull. \\
\hline
\end{tabular}

a Originally ringed as pull. on Skarvklakken 1984

${ }^{b}$ Originally ringed as pull. on Skarvklakken 1985

'Originally ringed as pull. on Skarvklakken 1989

of the unknown breeding status of the birds on the nest (actual breeders, pre-breeders, failed breeders or deferred breeders), actual counting errors and the possibility that some nests are hidden by the lie of the land (Nelson 2002, Wanless et al. 2005 , pers. obs.). The timing of the counts is also important, as illustrated in this study when incidental counts from the mainland documented the presence or absence of birds on e.g. Skarvklakken or Kvalnesflesa during seasons when aerial photography at a different time during the same season documented the opposite. Similarly there was an $11 \%$ discrepancy between an aerial count (308 occupied nests) and a ground count 10 days later (345 occupied nests) on St. Ulvøyholmen in 2008, partly a result of nests known from the ground being missed when counting on the aerial photographs (E. Pettex pers. comm.). These errors notwithstanding, we are confident that the surveys conducted since 1995 give a clear, overall picture of the fate of the Northern Gannet population in North Norway.

While the breeding population of the Northern Gannet nearly doubled in Finnmark (Storstappen and Syltefjord) since the last published census in 1995 (Table 1), that in Vesterålen and northern Lofoten decreased dramatically and in 2008 was only $30 \%$ of the maximum documented in 1991 (ca. 1500 occupied nests, Figure 3 ). This is mainly due to the decreases in the two largest colonies Skarvklakken and Hovsflesa whose populations both peaked in 1988-1991 with ca. 550 and 950 occupied nests respectively (Barrett \& Folkestad 1996), and which became extinct around 2007 and 2001 respectively (Table 1). However, concurrent with this decline, five small colonies in the region became established (St. Ulvøyholmen, Kvalnesflesa, Kvitholmen, Utfløysan and Fyllingen), of which the latter two are now extinct and the two first are presently declining. The one on Kvitholmen was established in 2008, and should perhaps be regarded as a satellite colony of Skarvklakken where birds have unsuccessfully attempted to breed several times over the last six years. A sixth colony at Kvitvær was also established during this period of decline and increased rapidly to 350-400 occupied nests within six years. 
It is reasonable to suppose that these new colonies were established by birds that had abandoned Hovsflesa and Skarvklakken, but unfortunately only St. Ulvøyholmen has been visited during the years of these surveys. However, 18 adults with rings were caught [eight in 2003 (H. Våge pers. comm.), one in 2007 and nine in 2008 (E. Pettex pers. comm.)]. Seven were last seen as chicks on Hovsflesa, and five on Skarvklakken (Table 2). Three had been ringed as adults on Hovsflesa, and two had been controlled as adults on Skarvklakken and one on Storstappen. Thus one third of the controls were of adults that had been controlled or ringed as breeding on one colony and had subsequently moved to St. Ulvøyholmen. Northern gannets normally have strong colony fidelity and according to Nelson (2002), there was, until now, no evidence of adults changing breeding colonies. Conditions were, however, exceptional as Skarvklakken was in a state of abandonment in 2003, such that this local movement of adult birds shows that when conditions at one site become unfavourable, adults will move to other sites. That as many as five of 18 controls were of local adult birds strongly suggests that these new colonies were indeed established by displaced adult birds as well as prospecting juveniles. The anomalous bird that had been controlled as an adult on Storstappen before returning to Vesterålen (Table 2) is more difficult to explain. It is, however, one of four records of movements between extant North Norwegian colonies of birds ringed or controlled as adults (pers. obs.). The other three were birds ringed as adults on Skarvklakken and later controlled on Storstappen in Finnmark, and these four controls are strong evidence that, contrary to previous suppositions (Nelson 2002) some adults do change colonies. That the population increase in Finnmark is simply due to movements of breeding birds from Lofoten and Vesterålen is, however, less likely as only three of the 95 controls of ringed adult birds on Storstappen between 1990 and 2008 were of birds ringed (or controlled) as adults (all on Skarvklakken). The remaining birds had been ringed as chicks in Lofoten and Vesterålen ( $n=65)$, on Storstappen itself $(n=21)$ and in Britain, the English Channel and Iceland ( $n=6)$ (unpubl. data).
What environmental stress is causing the decline in Lofoten and Vesterålen is unknown. Disturbance by humans was possibly the demise of Skittenskarvholmen, one of the first colonies established in Lofoten in the late 1970s (Barrett 1979), but this is less likely the cause of the abandonment of Skarvklakken and Hovsflesa as both were protected as nature reserves with severely limited access. A radical change in food availability is also unlikely for two reasons. Although not weighed and thereby not fully comparable, regurgitations documented on Skarvklakken during the period of decline (in 1996-2001) consisted mainly of Herring Clupea harengus and Mackerel Scomber scomber 25-35 cm in length (pers. obs.), both of which indicate access to an energy-rich diet. Had food availability been a limiting factor, it is unlikely that new colonies would have been established in the same region and well within the normal feeding range (up to $500 \mathrm{~km}$, Hamer et al. 2001, Garthe et al. 2007) of foraging gannets. Furthermore, the preliminary results of a study of the foraging ecology of gannets in the region also suggest that food is readily available (Pettex et al. 2008).

There is, however, strong circumstantial evidence that the decline was connected to the increase in the population of White-tailed Eagles Haliaeetus albicilla in the region. Since their protection in 1968 when numbers were very low, the population of White-tailed Eagles in Norway, and especially in North Norway has increased rapidly to 35004000 pairs (http://www.birdlife.no/organisasjonen/ nyheter/?id=357), and a breeding density of one pair per 12-14 km of coastline (Gjershaug et al. 1994). About half the Norwegian population breeds in Troms and Nordland where breeding success has been high in most years, and every autumn large numbers of eagles are regularly reported on and around the outer islands. Already in the early 1980s, harassment of large gannet chicks by White-tailed Eagles was repeatedly observed late in the breeding season from land on Skarvklakken by the warden of the reserve (B. Hus $\varnothing$ y pers. comm.). In the late 1990s, up to five eagles were counted leaving the islands when both 


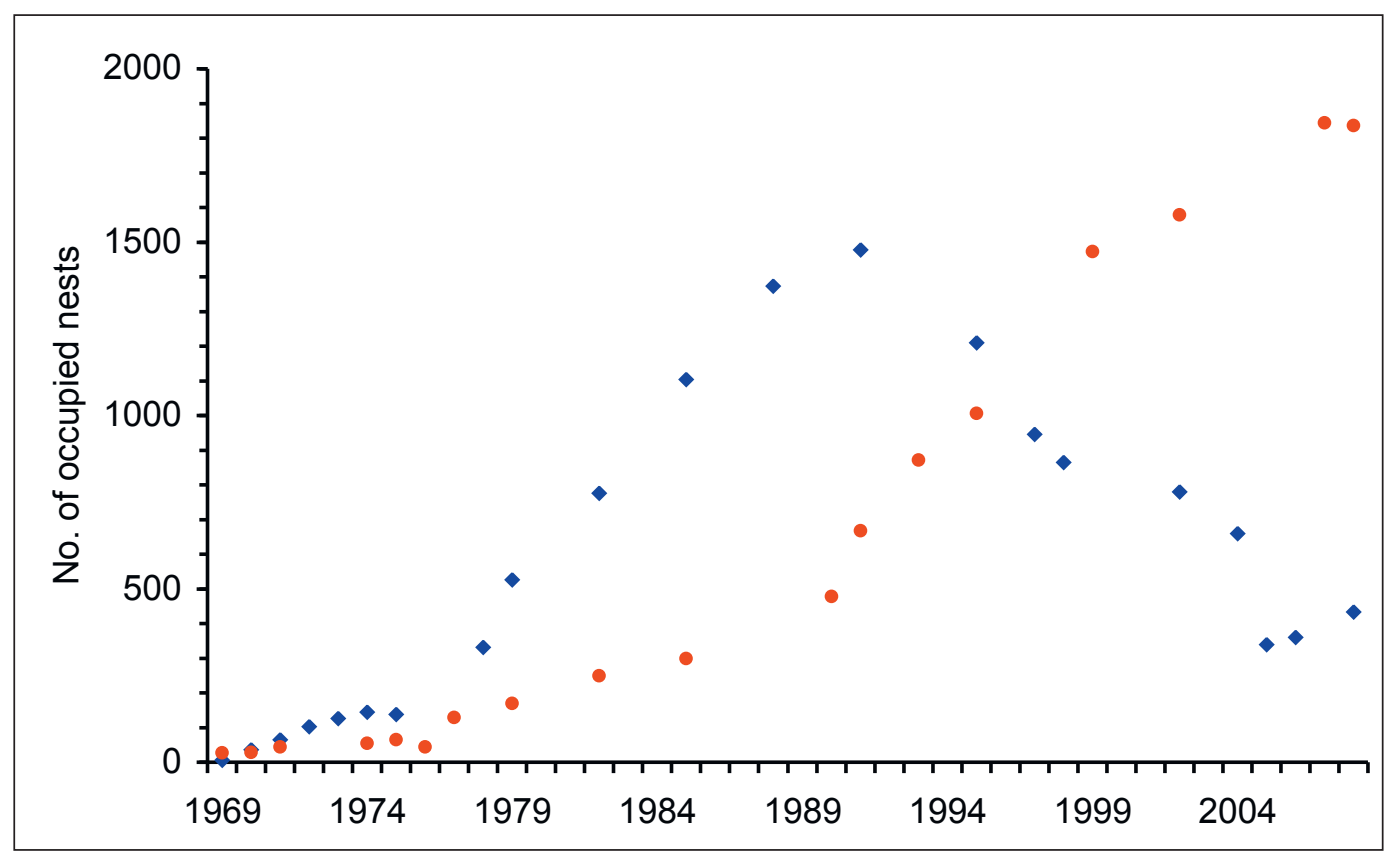

Figure 3. Counts of occupied nests of Northern Gannets in Finnmark (Storstappen and Syltefjord, red dots) and in Lofoten and Vesterålen (blue diamonds, excluding Buholmene) since their establishment in the region.

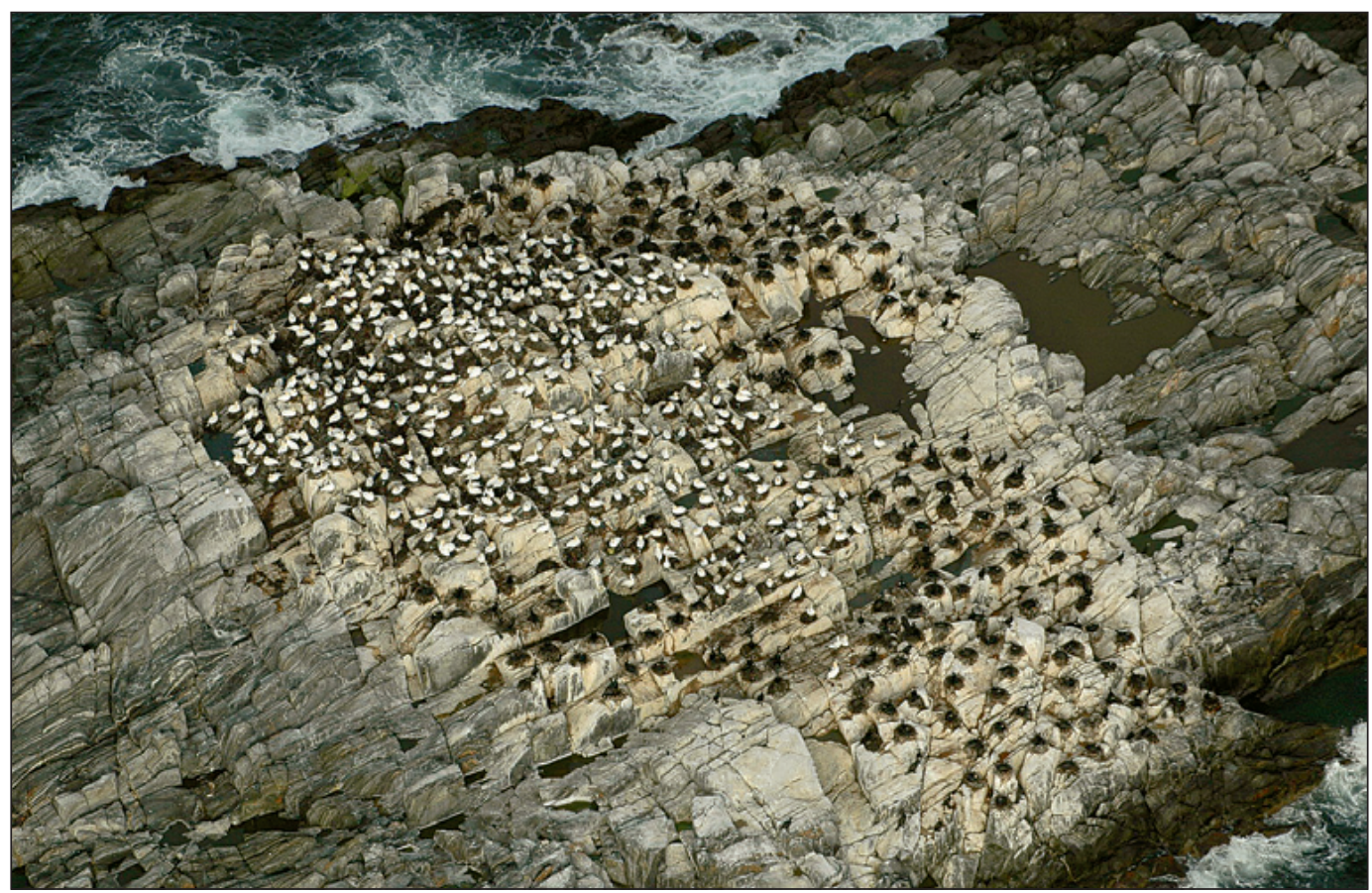

Figure 4. Aerial photograph of Northern Gannet and Great Cormorant colony at Kvitvar, Troms 27 June 2008. 
Hovsflesa and Skarvklakken were visited to ring chicks (pers. obs., H. Våge pers. comm.), and on aerial photographs of Skarvklakken taken in 1998, 10 eagles are visible standing round the periphery of the colony! In 2004, up to 16 eagles were seen around Fyllingen when visited in July (J.Lihaug \& R. Vagle pers. comm.). Furthermore, corpses and skeletal remains of adult gannets were found on the colonies, something which was extremely rare in the 1970s and 1980s. On Hovsflesa four corpses were found in 1997, 15 in 1998 and none in 1999 (H. Våge pers. comm.) and on Skarvklakken five were found in 1997, «several» in 1998, seven in 1999 and eight in 2001 (pers. obs.). There are also a record of a gannet ring found on the mainland $8 \mathrm{~km} \mathrm{SSW}$ of Hovsflesa in 2006 (eight years after it was used to ring a chick on Hovsflesa, H. Våge pers. comm.), and of the remains of an adult gannet in an eagle nest in 2006 (A. Oxem pers. comm.).

In 1999 and 2000, Skarvklakken was watched through a telescope from land over a period of four (1999) and seven (2000) days for a total of 36 hours to monitor interactions between the eagles and gannets (J. Stenersen, unpubl. reports). Between one and 14 eagles were seen on the island at any one time, and although no direct predation attempts of gannets on nests were ever observed, two unsuccessful attacks on adults standing in a 'club' were recorded. Eagles were, however, seen feeding on corpses of gannets on several occasions, and gannets sitting on the periphery of the colony were constantly threatening eagles as the latter approached the nests. No firm conclusion could be drawn from these studies, and it was suggested that the eagles might have been attracted to the colony by the amounts of fish regurgitated by agitated gannets. However, one eyewitness reported an eagle catching and killing an adult gannet that sat on the edge of the colony in 1998 (R. Harden pers. comm. to J. Stenersen) and in 2001 an eagle was seen repeatedly swooping down on an adult sitting on the water just off the colony and when approached more closely, the gannet was seen to be bleeding profusely from its head (pers. obs.). In 2004, an eagle was seen taking what looked like a gannet chick on Fyllingan (J. Lihaug pers. comm.). There can be little doubt that even if the eagles only rarely prey directly on the gannets, the continual presence of several individuals in (and above) the colony must cause enough stress to cause the gannets to finally leave the colony. It is also possible that their presence causes an indirect mortality through an increase in egg or chick predation by large gulls Larus spp. when gannets are temporarily distracted or frightened off their nests (Verbeek 1982, Parrish et al. 2001).

Why a similar harassment by white-tailed eagles is not evident in the colonies in Finnmark is unknown, but may be due to the topography of the sites at both Storstappen and Syltefjord. There gannets nest on steep cliffs among thousands of other seabirds and, although eagles are often seen patrolling these cliffs (pers. obs.), they do not concentrate on the gannet colonies as they do in the isolated colonies in Lofoten and Vesterålen.

Common for all the colonies in the Lofoten and Vesterålen region and at Kvitvær is that they were all established on exposed, low-lying, small islets on which Great Cormorants were already breeding. Where one would have expected spatial competition to develop between the two species, it seems that in all colonies there was an initial synergetic effect between them and in all cases both populations increased simultaneously during the first years. On Skarvklakken, there were 150-200 pairs of cormorants nesting on the island when the first four pairs of gannets nested there in 1967 (Brun 1972) and both populations increased (cormorants to 218 pairs in 1985 and gannets to 950 pairs in 1991, Barrett \& Folkestad (1996) \& unpubl. data) before declining. Similarly on Hovsflesa, the gannets established themselves among ca. 100 pairs of cormorants in 1975 and both populations increased (cormorants to 590 pairs in 1985 and gannets to 560 pairs in 1988) before both started to decline with cormorants abandoning the colony by 1995 and gannets by 2001. Also on Kvitvær, Kvalnesflesa and Fyllingen, both populations increased during the first years of gannet colonisation and on Kvitholmen, the cormorant population was larger in 2008 than in 2006 despite colonisation by 50 
pairs of gannet in 2008. However, common for at least five of the colonies (Skarvklakken, Hovsflesa, St. Ulvøyhomen, Kvitholmen and Kvitvær), the gannets occupied the middle of the island and cormorants were restricted to outside the perimeter of the gannet colony and thus probably to inferior quality sites (Fig. 4). A possible result of this is the start of the decline in cormorant numbers some years before that of the gannets as seen on the largest colonies Skarvklakken and Hovsflesa.

\section{ACKNOWLEDGEMENTS}

Many thanks are due to my informants Espen Bergersen, Harald Bergmann, Frank Christensen, Bergaton Hus $\varnothing y$, Jack Lihaug, Karl Otto Jacobsen, Alf Oxem, Emeline Pettex, Bjørn Røsshag, John Stenersen, Roger Vagle, Wim Vader and Harald Våge for their invaluable pieces of information received over the years. Arne Follestad sent me aerial photographs of Kvitvær taken in 2007, and Gunder Jensen piloted the aerial surveys. The surveys were financed by the National Monitoring Programme for Seabirds (organised by Svein Håkon Lorentsen, NINA, Trondheim) and the analysis was partly supported by SEAPOP (Seabird population management and petroleum operations, www.seapop.no). Svein Håkon Lorentsen and Emeline Pettex kindly commented on an early draft of the manuscript.

\section{SAMMENDRAG}

Siden den siste publiserte oversikt over utviklingen i den norske bestanden av havsule Morus bassanus (Barrett \& Folkestad 1996) har det vært en økning i Nord-Norge fra ca. 2200 par (definert som okkuperte reir) i 1995 til ca. 2700 par i 2008. Bestanden i Lofoten og Vesterålen har imidlertid gått tilbake fra 1500 par i 1989 til 500 i 2008, og de to største koloniene på Skarvklakken og Hovsflesa er forlatt. Flere mindre kolonier ble etablert i regionen i samme periode, men alle er ustabile. En ny koloni ble etablert i Troms i 2001. Kolonien $\varnothing k$ te til 400 par i 2007, men minket igjen i 2008 til 326 par. Forstyrrelse og predasjon fra havørn Haliaeetus albicilla er drøftet som hovedårsak til tilbakegangen i Lofoten og Vesterålen.

\section{REFERENCES}

Barrett, R.T. 1979. Changes in the population of gannet Sula bassana in North Norway. - Fauna Norvegica Ser. C, Cinclus 2: 23-26.

Barrett, R.T. 1981. The 1979 population of Gannets Sula bassana in North Norway. - Proceedings Second Nordic Congress of Ornithology 1979: 85-87.

Barrett, R.T. \& Folkestad, A.O. 1996. The status of the North Atlantic Gannet Morus bassanus after 50 years in Norway. - Seabird 18: 30-37

Brun, E. 1967. Hekking av havsule, Sula bassana, i NordNorge. - Sterna 7: 1-11.

Brun, E. 1972. Establishment and population increase of the gannet Sula bassana in Norway. - Ornis Scandinavica 3: 27-38.

Folkestad, A.O., Follestad, A. \& Valde, K. 1980. The Great Skua Stercorarius skua in Norway and the Spitsbergen area. - Fauna norvegica Ser. C, Cinclus 3: 55 .

Garthe, S., Montevecchi,W.A., Chapdelaine, G., Rail,J.-F. \& Hedd, A. 2007. Contrasting foraging tactics by northern gannets (Sula bassana) breeding in different oceanographic domains with different prey fields. - Marine Biology 151: 687-694.

Gjershaug, J.O. Thingstad, P.G., Eldøy, S. \& Byrkjeland, S. (eds.) 1994. Norsk fugleatlas. Norsk Ornitologisk Forening, Klæbu. 551 pp.

Hamer, K.C., Phillips, R.A., Hill, J.K., Wanøess, S. \& Wood, A.G. 2001. Contrasting foraging strategies of gannets Morus bassanus at two North Atlantic colonies: foraging trip duration and foraging area fidelity. - Marine Ecology Progress Series 224: 283-290.

Montevecchi, W.A., Barrett R.T., Rikardsen,F. \& Strann, K.-B. 1987. The gannet population in Norway, 1985. - Fauna norv. Ser. C, Cinclus 10: 65-72.

Nelson, B. 2002. The Atlantic Gannet. Fenix Books Ltd., Great Yarmouth. 396 pp.

Parrish, J.K., Marvier, M. \& Paine, R.T. 2001. Direct and indirect effects: interactions between bald eagles and common murres. - Ecological Applications 11: 1858-1869.

Pettex, E., Lorentsen, S.-H., Barrett, R.T. \& Grémillet, D. 2008. The foraging ecology of Norwegian gannets.Pp. 26-31 in Anker-Nilssen, T., Barrett, R.T., Bustnes, J.O., Christensen-Dalsgaard, S., Erikstad, K.E., Fauchald, P., Lorentsen, S.-H., Steen, H., Strøm, H., Systad, G.H. \& Tveraa, T. SEAPOP studies in the Barents and Norwegian Seas in 2007. NINA Report 363, Trondheim.

Vader, W. 1980. The Great Skua Stercorarius skua in Norway and the Spitsbergen area. - Fauna norv. Ser. C, Cinclus 3: 49-55

Verbeek, N.A.M. 1982. Egg predation by northwestern crows: its association with human and bald eagle activity. - Auk 99: 347-352.

Våge, H. \& Stenersen, J. 2003. Havsule i Nordland - en statusrapport. - Havørna 14: 38-39.

Wanless, S., Murray, S. \& Harris, M.P. 2005. The status of the northern gannet in Britain \& Ireland in 2003/04. - British Birds 98: 280-294. 